\title{
What Constitutes Failure? The Influence of Public Interests in Securing Accountability in Triple Helix Initiatives
}

\author{
Anna Thomasson \\ Lund University, School of Economics and Management, Lund, Sweden \\ anna.thomasson@fek.lu.se \\ Caroline Wigren-Kristoferson \\ Department of Urban Studies, Malmö University, Malmö, Sweden \\ Christin Scheller \\ Sten KJohnsson Centre for Entrepreneurship \\ Lund University, School of Economics and Management, Lund, Sweden
}

\begin{abstract}
The focus of this article is to examine a specific case of a failing regional innovation system (RIS). Our study focuses on a specific project that was conducted in a triple helix constellation where public actors occupy the centre of the triple helix constellation. By examining and interpreting this single case, we aim to illustrate the consequences that result from uncertainty over who the triple helix constellation is accountable to as well as the consequences that has for the overall assessment of the outcome of the triple helix. We show how the overall initiative constituted a failure, but when one considers the activities that were organized and implemented by the RIS, then it is problematic to define it as a failure. This leads us to the conclusion that we should evaluate RIS from different perspectives and on different levels, and we need to consider the time dimension in our evaluation.
\end{abstract}

\section{Keywords}

accountability - public sector - Triple Helix - wicked problems 


\section{Arabic}

\section{ما الذي يشكل فشلاًٌ دراسة حالة عن كيفية ضمان المساءلة في مبادراث المراوح الثلاثةالثلاثية}

Anna Thomasson, Caroline Wigren Kristoferson and Christin Scheller

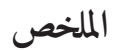

يهدف هذا المقال إلى درإسة حالة معينة من حالات فشل نظام الابتكار الإقليمي. ترتكز

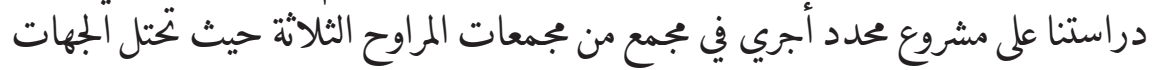

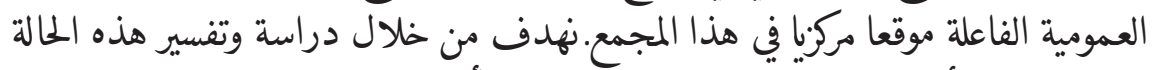

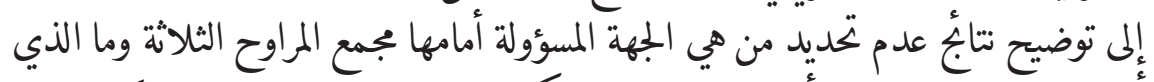

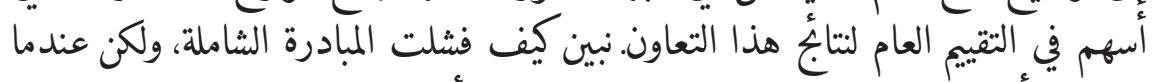

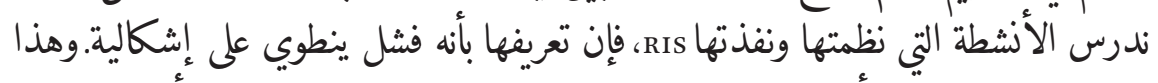

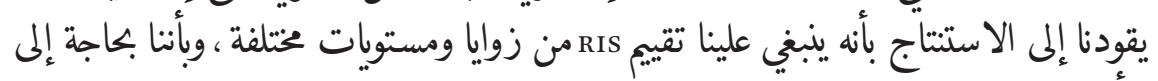
الأخذ بعين الاعتبار البعد الزمني في تقييمنا.

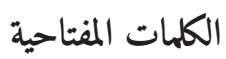

المراوح الثلاثة؛ القابلية للاختصاص؛ المشكل 


\section{Chinese}

\section{什么构成失败? 关于如何确保三螺旋行动中问责 制的案例研究}

Anna Thomasson, Caroline Wigren Kristoferson and Christin Scheller

摘要

本文聚焦于一个失败的区域创新体系的案例, 重点分析一个实施三螺旋模式的具体 项目, 这里公共部门占据三螺旋的核心。通过研究和解读这一案例, 我们旨在说 明矢于谁对三螺旋模式负责和负责什么这个两问题的不确定性对总体评估三螺旋部 门间合作的影响。我们揭示了这个项目的总体举措就是失败的, 但当评价中考量的 是区域创新系统组织和实施的活动, 则认定该案例失败是有问题的。这引出我们的 结论, 即我们应该从不同角度和层面来评价区域创新体系, 也需要在评估中考虑时 间维度。

\section{䏌键词}

三螺旋，问责，棘手问题，公共部门

\section{French}

\section{Qu'est-ce qu'un échec ? Une étude de cas des responsabilités dans des initiatives de Triple Hélice}

Anna Thomasson, Caroline Wigren Kristoferson and Christin Scheller

\section{Résumé}

L'objectif de cet article est d'examiner un cas spécifique de système d'innovation

régional défaillant. Nous examinons un projet spécifique qui a été mené dans une 
constellation de Triple Hélice au centre de laquelle se trouvent des acteurs publics. En analysant et en interprétant ce cas, nous visons à illustrer les conséquences que l'incertitude sur la responsabilité des acteurs et des actes dans la constellation de Triple Hélice a sur l'évaluation globale du résultat de cette collaboration. Nous montrons comment l'initiative a globalement échoué ; cependant, quand on considère les activités qui ont été organisées et mises en œuvre par les RIS, il n'est plus possible d'en arriver au même résultat. Nous en concluons qu'il faut évaluer les RIS sous différents angles et à différents niveaux, et tenir compte de la dimension temporelle dans notre évaluation.

\title{
Mots clés
}

Triple Hélice - Responsabilités - Problèmes pervers - Secteur public

\section{Portuguese}

\section{O que constitui fracasso? Um estudo de caso de como garantir a responsabilidade em iniciativas de hélice tripla}

\author{
Anna Thomasson, Caroline Wigren Kristoferson and Christin Scheller
}

\section{Resumo}

O foco deste artigo é examinar um caso específico de um sistema de inovação regional em falha. Nosso exame se concentra em um projeto específico que foi conduzido em uma constelação de hélice tripla, onde atores públicos ocupam o centro da constelação de hélice tripla. Ao examinar e interpretar este único caso, pretendemos ilustrar as consequências que a incerteza de quem a constelação de hélice tripla é responsável e para o que tem para a avaliação geral do resultado desta colaboração. Mostramos como a iniciativa geral constituiu um fracasso, mas quando se consideram as atividades que foram organizadas e implementadas pelo RIS, é problemático defini-la como um fracasso. Isso nos leva à conclusão de que devemos avaliar os RIs de diferentes perspectivas e em diferentes níveis, e precisamos considerar a dimensão do tempo em nossa avaliação. 
Palavras-chave

Helice Tripla - prestação de contas - problemas perversos - setor público

\title{
Russian
}

\section{В чем причины ошибок? Практические вопросы обеспечения контроля и учета в стратегиях тройной спирали}

\author{
Anna Thomasson, Caroline Wigren Kristoferson and Christin Scheller
}

\begin{abstract}
Аннотация
В фокусе данной статьи находится практический пример неудачной реализации региональной инновационной системы. Наше исследование рассматривает отдельный проект, реализованный в соответствии с принципами трехспиральной модели инноваций, в котором общественный сектор занимал центральное положение в спирали. Изучая и анализируя данный пример, мы постарались проиллюстрировать последствия неопределенности в вопросах отчетности и оценки эффективности взаимодействия в рамках тройной спирали. Фактически, мы показали негативный итог запуска данной инициативы, однако, учитывая ее региональный характер, сложно назвать его ошибкой. Это позволило нам сделать вывод о том, что мы должны оценивать региональные инновационные системы с разных точек (потенциал роста и уровень экономического развития), а также необходимость учета в подобной оценке временного фактора.
\end{abstract}

\section{Ключевые слова}

тройная спираль - прослеживаемость - злободневные проблемы - публичный сектор 


\title{
Spanish
}

\section{¿Qué constituye un fracaso? Un caso de estudio sobre cómo asegurar la rendición de cuentas en iniciativas de triple hélice}

\author{
Anna Thomasson, Caroline Wigren Kristoferson and Christin Scheller
}

\section{Resumen}

El enfoque de este artículo es examinar un caso específico de un sistema de innovación regional fallido. Nuestro examen se centra en un proyecto específico que se llevó a cabo en una constelación de triple hélice donde los actores públicos ocupan el centro de la constelación de triple hélice. Al examinar e interpretar este caso, nuestro objetivo es ilustrar las consecuencias que tiene la incertidumbre de ante quién es responsable la constelación de la triple hélice y de qué tiene para la evaluación general del resultado de esta colaboración. Mostramos cómo la iniciativa en general constituyó un fracaso, pero cuando se consideran las actividades que fueron organizadas e implementadas por el RIS, entonces es problemático definirlo como un fracaso. Esto nos lleva a la conclusión de que debemos evaluar las RIs desde diferentes perspectivas y en diferentes niveles, y debemos considerar la dimensión del tiempo en nuestra evaluación.

\section{Palabras clave}

Triple Hélice - Rendición de Cuentas - Problemas Perversos - Sector Público

\section{Introduction}

Initially, systems of innovation focused on national innovation systems (Freeman, 1987; Lundvall, 1988, 1992). However, during the 199os, interest in regional innovation systems (RIS) increased (Cooke, 2005). Wealthy regions were seen as the building blocks of wealthy nations (Amin, 1999). An RIS is the product of interaction between different actors, e.g., research institutions and higher education institutions, technology transfer agencies, business associations, and 
financial institutions. These different actors support innovation processes by virtue of their special competencies (Asheim and Isaksen, 2002).

Systems of innovation can be considered as an academic phenomenon, both instantiating a theoretical area and an empirical phenomenon worthy of study. The worlds of academia and policy-making are socially interlinked, and consequently academic models, theories, and concepts have become tools and a technical language for policy-makers to employ. Sharif (2006) discusses the emerging social construction of national innovation systems (NIS) and argues that there exists a lack of consensus whether the concept of a "national innovation system" was an academic or a policy-related concept when it was first proposed. He observes that the main actors in its initial phases held dual roles in academia and in policymaking activities. Sharif argues that:

We can hypothesize that in their work these actors deployed two sets of rhetoric depending on the hats they were wearing or the positions they filled at a given time. In this way, these skilled actors were able to take advantage of the looseness and ambiguity associated with the NIS concept (...) to enhance its appeal to either audience depending on the purpose they were trying to achieve.

SHARIF, 2OO6: $75^{2}$

A consequence of this historical development in the field of systems of innovation is that there is a tendency to take a very positive approach to systems of innovation. However, notwithstanding this, we argue that there is currently a lack of studies that have investigated cases where systems of innovation did not work as expected (Isaksen and Nilsson, 2013). In this article, we address how difficult it is to succeed when "wicked" problems are to be solved.

To achieve the above, we use the concept of "accountability" in our analysis. Accountability refers to the everyday processes of giving, demanding, and receiving accounts (Roberts and Scapens, 1985; Munro and Mouritsen, 1996). These processes account for actions and are thus central to any organizing effort. Adopting a perspective which takes accountability into account is a valuable tool which can be used to further understand the organizing process of a RIS and triple helix processes. Using this perspective, we can pose the following research question: How are triple helix processes made accountable? In interpretive studies of accountability, such as this study, other central questions that should be asked are: "[W]ho is accountable to whom and for what?" (Bovens, 2009). Even if the procedures for giving account are clearly defined, the actual processes of accountability are often complex and problematic. Several 
accountability relations are present in triple helix collaborations but, to the best of our knowledge, these relations have not yet been thoroughly investigated.

Rather than assuming that a regional innovation system is an outcome of sound control and governance structures, this article uses the framework of accountability to interrogate "who is accountable to whom and for what?" and to relate the understanding that we develop from doing this to the industry contexts that the participating organizations operate in. We show that, because each industry follows its own logic, it is not obvious what should be accounted for and who should be held accountable for certain events.

RIS studies tend to examine technological innovations. They are also often focused at the later stages in the linear model of innovation and assume a chronological order of events that starts with an invention being developed and then later diffused by private firms (Godin, 2006). These studies also consider the presence of an entrepreneurial university (Etzkowitz and Klofsten, 2005). The phenomenon of economic growth is also examined in such studies. This makes sense because regional clusters, which consist of private, forprofit companies, are at the centre of RIs that are supported by other actors. However, in the present study, we demonstrate that when public actors are at the centre of a RIS, events can unfold quite differently. The role of the public sector in a triple helix collaboration, as recognized in a more recent study by Larsen et al. (2018), remains a role that is under-researched. This is also recognized by Cai and Etzkowitz (2020) stressing the need to in research on triple helix constellation recognize the different levels of government. By situating ourselves in this gap in existing research on triple helix and by addressing the role of the public sector in triple helix collaborations, we aim to contribute to existing knowledge about triple helix collaborations.

The purpose of this study is thus to answer the research question: "Who is accountable to whom and for what?" in a triple helix collaboration where the public sector plays an important role. For this purpose, we apply the concept of "accountability" and examine a specific case of a regional innovation system.

To fulfil the purpose, we followed the mobilization process of a particular RIS and closely observed the different activities that were performed by the people working in the RIs. Our examination focuses on a specific project that was conducted in a triple helix constellation where public actors occupy the centre of the triple helix constellation. We show how the overall initiative constituted a failure, because it no longer received further governmental funding. However, we will also show that when one considers the activities that were organized and implemented by the RIS, then it is problematic to define it as a failure. By examining and interpreting this one case and by focusing on one 
specific project, we aim to illustrate the consequences that uncertainty of who the triple helix constellation is accountable to and for what has for the overall assessment of the outcome of this collaboration. This leads us to the conclusion that we should evaluate RIS from different perspectives and on different levels, and we need to consider the time dimension in our evaluation.

\section{Accountability as the Theoretical Framework}

Accountability is a concept that has changed in terms of its theoretical role and scope over time (Mulgan, 200o). In its broader sense, it is associated with transparency, democracy, responsibility, good governance, and responsibility, amongst other things. According to Mulgan (2000: 555), however, what lies at the core of accountability is the process by which someone is held accountable. This approach to the concept of "accountability" is similar to the definition provided by Bovens (2009), who defines it as a process of giving account and holding someone accountable. Consequently, for accountability to be secured, a relationship of accountability needs to be established. Thus, the question: "Who is accountable to whom?" (Bovens, 2009). In addition, the question of "Accountable for what?" should be addressed since the definition of the concept notes that the person who is supposed to be held accountable is also accountable for something quite definite. What we need to establish is thus (i) the forum in which accountability is claimed (who is accountable to whom), and (ii) the content or type of performance that is expected (the For what? part of the question) (Bovens, 2007).

\section{3}

\section{Relations of Accountability}

The person who is to be held accountable needs to respond to requests that may be made of him or her, by taking account (Greiling and Spraul, 2010), and the person who is to be held accountable needs to recognize the authority or the right of the other person who holds him or her accountable (Gray and Jenkins, 1993; Sinclar, 1995). Accountability, thus envisaged, is a process that involves an exchange of information between persons or organisations. For this process to work, information needs to be available about the performance of a person or an organisation, i.e., transparency is required (Bovens, 2009; Mulgan, 2000). The question of accountability, and how accountability can be secured, can thus also be regarded as a striving to find an alignment between the expectations of an organisation and the actual performance of 
that organisation (Huse, 2005). Consequently, in relation to the creation of accountability, the issue of setting the right expectations must be addressed, so that the organisation is not judged in terms of the wrong criteria (Zambon and Del Bello, 2005). Responsible individuals and organisation supply (and demand) the accounts that are considered suitable in a particular context. This entails that "to be competent and trusted means to be able to distinguish between discourses and to perform to expectations in the intended context" (Solli and Jönsson, 1997: 19). This implies that, if organisational actors in their role as responsible and trusted managers, business partners, and/or colleagues fail to adhere to legitimate methods of accountability in a certain context, then they run the risk of losing their membership.

Previous studies on accountability show that the creation of accountability involves different dimensions of an organisation, as well as different actors or stakeholders, at different levels within and outside an organisation (Munro and Mouritsen, 1996; Sinclair, 1995; Bovens, 2009). We thus note that in the literature, different forms of accountability are discussed (Cooley, 2020). One of these forms is based on existing hierarchical and top-down relationships within an organisation, where the principal holds the agent to account (Cooley, 2020; Romzek and Dubnik, 1987). In addition to the hierarchical form of accountability, a more holistic approach is also recognized in the literature (Cooley, 2020). A holistic form of accountability not only includes the relationship between a superior and a subordinate, but includes other stakeholders as well (Cordery et al., 2010). In a holistic approach to accountability, organisations are considered to be accountable to several stakeholders, and not only for short-term performance, but also for long-term strategic goals (O'Dwyer and Unerman, 2007).

We also claim that horizontal forms of accountability may exist. In such cases, accountability emerges as a result of the fact that collaborative partnerships between organisations from different sectors are growing in number, as public organisations strive to meet challenges related to wicked problems (Klijn et al., 2010; Klijn, 2008). In cross-sector collaborations, hierarchical relationships are supplemented with horizontal relationships that bridge over different sectors (Hodges, 2012; Shaoul et al., 2012; Willems and Van Dooren, 2012). From a horizontal perspective, actors who, by virtue of their membership in a triple helix, participate in cross-sectorial collaboration hold the triple helix accountable for how the triple helix performs. From a vertical perspective, actors who participate in the triple helix are held to account by their stakeholders. However, this description does not completely describe the complexity of the situation. 
Expectations that are placed on an organisation differ, depending on the type of organisation and the context in which it operates. Note that accountability is context specific (Roberts and Scapens, 1985; Cooley, 2020). In cross-sector collaborations, there is, therefore, a risk that the question of "Who is accountable to whom and for what?" becomes blurred, because each of the actors who is participating in the triple helix may have different expectations with respect to what the triple helix is supposed to perform. These expectations are related to what each sector believes creates value, and, thus, what constitutes "good performance".

Public sector accountability rests on the democratic system (Watson, 2003). Citizens elect politicians who are held accountable towards the citizens, with respect to how they govern and how they efficiently provide public sector services (Bovens, 2009; Mulgan, 2000). The accountability system in the public sector is thus built upon hierarchical relationships and is regarded to consist of four different types of accountability: (i) bureaucratic accountability, (ii) legal accountability, (iii) professional accountability, and (iv) political accountability (Romzek and Dubnik, 1987; Greiling and Spraul, 2010; Mulgan, 200o; Bovens, 2009). The first type of accountability, bureaucratic accountability, refers to the relationship between a superior and a subordinate within the government. Legal accountability encompasses the rules and regulations that governments legislate and are subject to, and professional accountability is the control that is executed among peers. Finally, political accountability refers to the relationship between elected politicians and the citizens. In addition to identifying to whom politicians are accountable, we must also ask "For what are they accountable?" This question focuses our attention on the content of the relationship. In more recent research on public sector accountability, the "For what?" question in the public sector is considered to be constituted by a combination of financial performance and non-financial performance (Bracci et al., 2015).

In the private sector, a different set of rules with respect to accountability are followed. In the private sector context, accountability is directed towards the market, towards other players on the market, and the legal system regulating the market (Watson, 2003). Traditionally, the measure of private sector accountability has been made in terms of financial performance, and the process of accountability has been closely associated with accounting, auditing, and the provision of information in financial reports (Roberts and Scapens, 1985; Cooley, 2020). More recently, however, we can see a shift towards including also other values in addition to financial values with the development of 
different types of environmental and sustainability interests (Cooley, 2020; Cooper and Owen, 2007; Morgera, 2020).

Taking the above discussion of accountability into account, we can assume that when organisations from different sectors collaborate with each other, as they do in a triple helix constellation, for example, the question of who is accountable to whom and for what becomes somewhat more complex. When we consider how the "For what?" question differs between sectors, we note that expectations also differ between sectors. This is something that previous research into conflicts of interest in triple helix constellations also confirms (Attonen et al., 2018, Thomasson and Wigren-Kristoferson, 2020).

In addition to expectations that are related to the public sector and the private sector, a triple helix constellation also encompasses the expectations of a university. Traditionally, universities rest on values like meritocracy, collegiality (Foss Hansen et al., 2019), as well as academic freedom and professional autonomy (Huisman and Currie, 2004). However, more recently universities have experienced a change in terms of an increased focus on accountability (Huisman and Currie, 2004) which is related to performance in terms of excellence, social impact, and effectiveness, to gain the trust of various groups of stakeholders (Foss Hansen et al., 2019). The combination of traditional academic values and the more recent focus on accountability and performance has given rise to tensions within academia (Macfarlane and Burg, 2019; Kearns, 1998). Thus, in addition to public sector and private sector types of accountability, in a triple helix constellation we find a third species of accountability, namely that which is pursued by universities. Accountability, in the context of university setting consists of a combination of efficiency and output performances and political interests. Consequently, universities thus combine values that public sector and private sector accountability aim at securing. Brown (2017) has identified as many as seven different types of accountability, or, what he refers to as, "seven silos of accountability" (Brown, 2017). Adding to the complexity of the triple helix is the inherent conflict that still exists within universities between this more recent focus on accountability and traditional academic values (Macfarlane and Burg, 2019; Kearns, 1998).

When actors from different sectors collaborate with each other in a triple helix constellation, not only is accountability claimed by different forums, but the content of accountability differs, depending on the forum. Thus, in a triple helix constellation, the question of "Who is accountable to whom and for what?" does not have one simple answer, but, instead, it has several. This combination of different relationships with accountability creates what Koppell (2005) refers to as a "multiple accountability disorder". It also creates a situation where it is more challenging to find alignment between the expectations 
TABLE 1 Summary of types of accountability and content for different types of actors/sectors

\begin{tabular}{lll} 
Actor & Type of accountability & Content \\
\hline $\begin{array}{l}\text { Public sector } \\
\text { organization }\end{array}$ & $\begin{array}{l}\text { Hierarchical based on the } \\
\text { democratic system: } \\
\text { Legal, political, bureaucratic, and } \\
\text { professional types. }\end{array}$ & $\begin{array}{l}\text { Financial and non-financial } \\
\text { performance. Public value and } \\
\text { non-financial performance } \\
\text { dominate. }\end{array}$ \\
Private sector \\
organization & $\begin{array}{l}\text { Hierarchical with focus on } \\
\text { performance and the chain of } \\
\text { command. }\end{array}$ & $\begin{array}{l}\text { Financial performance and social } \\
\text { responsibility }\end{array}$ \\
& $\begin{array}{l}\text { Horizontal based on rules of } \\
\text { market and competition. }\end{array}$ & \\
Academia & $\begin{array}{l}\text { Horizontal based on values. } \\
\text { Hierarchical based on } \\
\text { performance. }\end{array}$ & $\begin{array}{l}\text { Values: meritocracy, collegiality, } \\
\text { academic freedom, professional } \\
\text { autonomy. } \\
\text { Triple Helix }\end{array}$ \\
& $\begin{array}{l}\text { Horizontal and hierarchical } \\
\text { Corformance: excellence, impact. }\end{array}$ & $\begin{array}{l}\text { Combination - risk for multiple } \\
\text { accountability disorder. }\end{array}$
\end{tabular}

SOURCE: THE TABLE IS BASED ON THE REVIEW OF PREVIOUS RESEARCH ON ACCOUNTABILITY PRESENTED IN LITERATURE REVIEW OF THE ARTICle.

of an organisation and the actual performance of that organisation (Huse, 2005). To illustrate the combination of different types of accountability that can be found in a triple helix constellation a summary of the above presented literature on accountability can be found in Table 1 below. Table 1 does not only summarize the differences between sectors in regard to type and content of accountability, it also includes the hierarchical and horizontal dimensions of accountability and shows how the different types and variations in content intersect in the triple helix constellation.

\section{$5 \quad$ Method}

Two of the three authors of this article conducted empirical field research, which is the base for the presented study. The RIs received state funding. ${ }^{1}$ The governmental organization financing the RIS program demanded that $5 \%$ of the total budget should be dedicated to research; research is considered important from a learning perspective. One of the authors followed the overall 
program but not individual projects. She studied the overall program during a 5-year period (2014-2019). In her role as a researcher, she participated in meetings, board meetings, and other activities that were organised within the RIS project. During this period, she participated in approximately 45 meetings, i.e., almost 200 hours of discussion. During these meetings she took notes and documented the RIS process and associated activities. These notes have been important to the development of the narrative that is shared in this article. Additionally, approximately sixty interviews were conducted with involved actors during the same period. The interviews were recorded and transcribed. Over the period, a series of formal and informal conversations and interviews were also conducted. Furthermore, the researcher was granted access to documents relevant to the work done at the RIS, e.g., applications, reports, notes from meetings, and media material.

During the five years she was not involved in strategic decision making, which implies that the research cannot be defined as participatory action research (McIntyre, 2008), rather as ethnographic inspired research (Prasad, 2005). It is difficult to strictly say how much the presence of a researcher influences the process being studied. When in-depth field studies, lasting over longer periods of time, the researcher most often does have an explicit or implicit influence as relationships are developed over time.

The other author that has been engaged in field studies studied the specific project that is discussed here, From table to soil. She was engaged as a consultant in the very early phase and did later on conduct retrospective interviews. The narrative that is presented in this article is based on real-time reflections and interpretations of the empirical material that was collected in connection with the RIs project.

We argue that if one is to understand certain initiatives that have failed (as in the case under investigation here) it is important that one bases one's analysis on an extensive empirical material. To achieve this, the case study approach is well suited. The longitudinal aspects of the study imply that we can build on rich, ethnographically inspired material. Consequently, we employ an "interpretivist" methodology (see Prasad, 2005). The insights gained from the empirical case study allowed us to engage in a discussion of why the project failed.

We focus on one specific project at the RIS that was organised as a triple helix project. We describe the process that took place within the project and identify the challenges that the project was faced with.

The analysis took the point of departure in the accountability framework presented in Table 1. In our analysis, we focused on identifying a number of critical themes that are relevant to a proper description of why the project was not successful. Our analysis revealed three main themes. The first theme 
was concerned the challenge of conducting innovation in a municipal context, i.e., being subject to a different organisational logic than the logic of the private market. The second theme highlighted the conflicting logics that existed among the collaborating members in the RIS process, namely the triple helix project, since the participating actors represented different sectors and thus represented different organisational logics. Finally, the third theme was the dimension of time that the project was constrained by.

\section{The Context of the Study}

In Sweden, theories on RIS are operationalized through the work that is conducted by The Swedish Agency for Innovation Systems, Vinnova. This agency works with the following tasks (Jacob, 2006): (1) advising the government on innovation policy on an annual basis; (2) performing in-house research and commissioning research on innovation; (3) designing and implementing policy programs that are aimed at stimulating innovation. Vinnova manages a program that supports the development of Ris called Vinnväxt.

The Vinnväxt program was initiated in 2001, when Vinnova was inaugurated. Whilst the program was designed to be a competition for the various counties in Sweden, it supports the development of sustainable growth in regions which have the potential to be internationally competitive within a period of ten years. Funding from Vinnova must be matched by funding from the local county. This funding supports the running of research and innovation environments. Another prerequisite for the program is that it must include a regional triple helix team that collaborates in developing the county's strategic idea, based on the county's conditions.

In total Vinnova has funded 17 RIS through the Vinnväxt program. Vinnova funds a RIS over a 10 years period. The money from Vinnova should be jointly financed with reginal money from different regional triple helix actors. Depending on the ability to mobilize regional money, Vinnova finances each RIS between $0,5^{-1}$ million Euro per year.

The RIS that we focus on in this study, involving urban supply systems, was awarded funding from Vinnväxt. It received its initial funding from Vinnova in 2012, whilst it was a planning grant to write an application for a Vinnväxt competition. The program handed in an application, and in 2013 they received an additional SEK 4 million to work on the county level to bring the different triple helix actors together. In 2016, the group was awarded funding for a 10-year project. The Ris planned to develop so-called "smart growth" by focusing on (i) knowledge and innovation, (ii) sustainable growth through a greener economy, and (iii) increasing growth in firms in the industry, and thereby, new jobs. 
Urban supply systems play several important roles in the development of a sustainable society, since they relate to renewable energy production, heating, waste management, recycling, and water-related issues. These complex and often "wicked" areas of operation involve several actors. In Sweden, municipal authorities are responsible for urban supply systems. This role entailed that the local municipality was involved in the innovation process. However, they did not need to solve these wicked problems alone because they were expected to collaborate with other actors who had an interest in this area, including academia and several private companies.

When the process began and application for funding to develop a RIS was initially made, the main idea was to develop and then sell sustainable solutions for the urban supply of waste, energy, and water. The region was previously known for having implemented a number of urban development projects which had high environmental profiles. To realise these projects, a number of municipalities cooperated with the energy sector, with water and waste management organisations, and with real estate companies, throughout the duration of the projects. The idea was that these systems would be marketed and sold world-wide. However, urban development projects are very complex and are unique to each local context. It is seldom the case that "one model fits all". In projects like these, it is the municipality who makes the final decisions. If new systems are not taken into consideration in the physical planning of an area, then it is impossible to implement these new systems. The high-profile projects in the region receive a lot of attention, and it is quite certain that other cities will learn from these systems and even adapt some of them. However, we note that market aspects, including regulations, legal requirements, and political governance also hold influence over such projects.

The host organisation for the Vinnväxt program that is studied in this article is an organisation that specifically works with triple helix projects that are related to the clean-tech industry. The organisation organises resources and competencies from different organisations and sectors to solve "wicked problems" (Head and Alford, 2015; Rittel and Webber, 1973). The activities that the host organisation organises are performed in networks which include members from different organisations and sectors.

Several wicked problems were initially addressed by the Vinnväxt program, each of which were organised as a separate project. In this article, we examine one such project.

The project was organised and carried out by representatives from different organisations and sectors representing the triple helix actors. Part of the initial application for this particular RIS was to start seven testbeds. One of these testbeds was an industry park located in one of the municipalities that is involved in the RIS project. However, in the spring of 2019, the host 
organisation was informed that the RIS project (after being subject to an international evaluation) had not achieved its goals and should, therefore, not receive further funding.

The RIS initiative was unique because three municipalities located in the south of Sweden formed the core of the initiative. The fact that the main actors in the RIS were municipalities was because the primary focus of the RIS initiative was urban supply systems. Note that these systems are owned and maintained by municipalities, and not by private actors.

It was not obvious when the initiative was initially mobilized that three municipalities would be involved in the project. Originally, the large "cleantech" sector in the south of Sweden was a driving force behind the initiative. However, over time it became apparent that the private sector was in a subordinate position relative to the public sector, since the municipalities would be the owner of the systems and also be the customer who would pay for the systems.

A Wicked Problem Translated into the Project Called From Table to Soil

As mentioned above, the projects that the RIS worked with were so-called "wicked problems" (Rittel and Webber, 1973). The problems that the project would tackle was decided by the RIs's management group. Each project group within the RIS needed to initiate collaboration between different parties, because no one individual actor can solve a wicked problem alone. Consequently, each project group hosted participants from academia, the business sector, the public sector, and (in cases) from civil society. The project group was loosely composed, depending on the phase that the project was in and the problem that different actors were involved in addressing. The manager of the group had a strong connection to the program group and the host organisation of the Vinnväxt program. An overview of the participants in the project group is provided in Table 2.

Before we describe the project in more detail, we conclude that the municipal companies constituted the majority of representatives in the project group. The specific project that we investigated for this study was called From table to soil. The core aim of this project was to work with recycling technology and to transform food waste into biogas.

The general problem was articulated by the following question: How can we get more food waste out of apartment buildings and how can we create a product from this waste that agriculture wants? The solution to this problem was aimed at closing the food/energy cycle. The CEO of the municipal waste 
TABLE 2 The table is a summary of the participants in the project From table to soil. The table is constructed by the authors.

\section{Sector Participants}

$\begin{array}{ll}\text { Academia } & \text { 1. Male, (no PhD) focus on methods and technology for biomass } \\ & \text { production, Swedish University of Agricultural Sciences. } \\ & \text { 2. Male, professor, focus on sustainable development, Lund } \\ & \text { University } \\ \text { 3. Male, focus on sustainable development and mobility, } & \text { Lund University } \\ \text { Municipality } & \text { 1. Project manager, female, strategic department (Hbg) } \\ & \text { 2. Female, Environmental department, (Lund) } \\ & \text { 3. Female, Environmental department, (Malmö) } \\ \text { 4. Female, Environmental department, (Hbg) } \\ \text { companies } & \text { 1. Female, waste company (Hbg) } \\ & \text { 2. Female, waste company (Hbg) } \\ \text { 3. Female, water company (Hbg) } & \text { 4. Male, waste company (Hbg) } \\ & \text { 5. Female, waste company (Malmö) } \\ \text { 6. Female, housing company (Hbg) } & \text { 7. Male, energy company (Kristianstad) } \\ \text { Interest } & \text { 1. Female, network organisation working with biogas on a regional } \\ \text { organisations } & \text { level }\end{array}$

2. Male, The Federation of Swedish Farmers

$\begin{array}{ll}\text { Region } & \text { 1. Male, Regional innovation company } \\ & \text { 2. Male, Regional innovation company } \\ \text { Private } & \text { 1. Female, technical consultant company } \\ \text { companies } & \text { 2. Male, biogas company }\end{array}$

company at one of the municipalities that took part in the project had initially introduced this wicked problem. As can be seen by the question above, the wicked problem consisted of a chain of separate and distinct problems that are linked to each other. Given this, it was difficult for the project group to appoint responsibility to specific parties for solving these problems. Four work tasks were identified as being relevant to the solution of the problem, all of which had different time horizons. The following tasks were identified: (i) create behavioural change; (ii) improve the collection of the waste; (iii) improve the biofertilizer (the waste product from the biogas plant); and (iv) determine the value of the biofertilizer. 
The first two tasks overlapped with each other and were focused on people's behaviour regarding how they sorted their food waste. In this context, the question was raised: How can we increase the amount of food waste that is collected from apartment buildings? The specific challenge consisted of getting people who live in apartment buildings to sort their food waste. A factor that had to be considered was that the distance to the rubbish bins is greater in an apartment complex than it is for people who live in villas, for example. The project group argued that the brown paper bags that people used for food waste needed to be replaced and so a local company developed an organic plastic bag for food waste. The new bag was tested among tenants in apartment buildings, and the pros and cons of the new organic plastic bag were evaluated. To learn how this change in bag impacted on the behaviour of the tenants, a "pick analysis" was conducted on the waste.

It was strongly believed by the project group that the organic plastic bag would play an important role in solving part of the problem that they were tasked to solve. It was also clear that they had placed a great deal of faith in the efficacy of the new type of bag. During the process, however, it became clear that replacing the paper bags with plastic bags was not as easy as they expected. In this regard, several challenges were identified, including:

(i) an evaporation process starts in a paper bag but not in an organic plastic bag;

(ii) an organic plastic bag is able to carry more liquid than a paper bag, which might allow for more liquid to be thrown away in the organic plastic bag;

(iii) the bio plant must (technologically) accept the new bag;

(iv) an organic plastic bag might be confused with a non-organic plastic bag and people might throw away plastic in their food waste, which would end up as micro-plastic pollution being spread across agricultural fields. In summary, an issue that seemed quite easy to solve, ended up as a rather difficult and complex problem.

In the project From table to soil, the organic plastic bag that was introduced to the public was not accepted by the bio plant. The previous test bags had been slightly thicker than the bags that were distributed to the public. The problem at the bio plant was that the new bags would break down and settle in all the filters. The decision was made to rebuild the bio plant, so it accepted the new organic plastic bags.

Regarding the third work task, the following question was raised: How can the waste from the biogas plant be refined and distributed to the fields by tankers, since the waste is in the form of a fluid? 
This question became central when the issue of turning the existing biofertilizer into a commercial product became relevant. In the case of this biofertilizer, no specific need for this biofertilizer could be identified, nor was there a solution to the problem of how it could be easily disposed of. It was also found that $90 \%$ of the biofertilizer that is produced is actually used, but it is expensive, since the biogas plant actually pays to get rid of the biofertilizer that it produces. These circumstances meant that one had to first identify and quantify the needs of different stakeholders related to biofertilizer. At this point, the project team tried to find combinations of interests in a new business model. Their purpose was to increase the profitability of the biofertilizer.

The biofertilizer that is produced at the biogas plant consists of 97 percent water and smells bad. The project team then asked: But what if it could be packaged into a product? Would there be a market for it? The first step they had to take was to learn about the nutritional value of the existing product. To take on this challenge, the project group worked with a consultant. This consultant further developed an NABC analysis (Need Approach Benefit and Competition) an analysis that had been developed by the Stanford Research Institute. This analysis is often used by actors who support new businesses. The "needs" in an NABC analysis is expressed in terms of a business opportunity. To identify the needs, relevant stakeholders were invited to join a workshop where the following questions were discussed: (i) What is your industry's biggest challenge right now? and (ii) Financially, what would it be worth if there was a good enough solution, taking care of the problem? Guided by the consultant the group discussed these questions in detail to understand the scope of the business opportunity.

As a second step to address the issue of the biofertilizer, a business case was developed, in which economic benefits were identified. The result of this collaborative process was that it was decided that the biofertilizer should be labelled as an "eco" product and it should be produced in the form of a solid, to reduce its transport costs.

The next step was to invite a number of actors together to discuss possible solutions to the proposals made. A market dialogue was organised as a "pitch and match" process. In such a process a defined problem is presented, and private companies are invited to pitch their solutions for how they would solve the problem. Several different private companies were invited to present their solutions to the problem. The two challenges involved devising a solution to how one can turn the fluid waste product from the bio plant into a solid product, and how this product could be eco-labelled. The Pitch and Match needed to be arranged in a way that would engage the companies, and so it was organised as a one-day meeting. The meeting started with a description of the challenge, presented by the CEO of the estate which owns the land on which the 
biogas plant is located. He is also the co-owner of the bio plant in question. After the challenge was introduced, the different private companies presented how they would solve the challenge. One reason why the companies participated in the Pitch and Match was that it provided them with a valuable opportunity to benchmark themselves against their competitors and learn from the other participating companies. In this specific case, one company that participated in the Pitch and Match process developed a product.

When all the companies had pitched their solutions, none of them had managed to meet all the demands of the problem at hand. It was clear that it was a very complex process, involving different actors. To determine the value of the biofertilizer product was one challenge, and another challenge was to ensure that the product was free from plastic.

In the city were the project was carried out, a new housing area was under construction. In this housing area, food waste disposal units had been installed in each apartment. There was also a system separating grey water from black water. To learn about the composition and nature of the waste that was produced by the people who lived in these apartments, a testbed was established. This minor project on food waste contributed with several insights and knowledge that was relevant to the RIs. The testbed has a display room where end users can learn about the system, which will, hopefully, result in an increased willingness to use the food waste disposal units that have been installed in each apartment.

The most important observations that was made whilst working with the project, From table to soil, is that the public sector must identify, early on in the process, which actors who will benefit from solving a problem/challenge. It is not obvious who these actors are, but they need to be involved in the process. However, if an actor is to get involved, then they must be able to see the value that their participation will bring them.

In the project under investigation, it was clear that the public plays an important role with regards to working with urban supply systems. This is primarily the case because the public is the end customer and, may be viewed the party that demands innovation. The private actors, on the other side, play an important role with respect to developing the innovation. This development can, however, be done in collaboration with the public.

\section{9 Moving beyond a Focus on Economic Growth to Social Impact}

The case described above illustrates that the project, From table to soil, was a process that consisted of several different steps. In each step different 
actors were involved, thus implying that the actors' accountability differed from one task to another. This was true for the stakeholders who held these actors accountable, too. Consequently, the answer to the question of "Who is accountable to whom and for what?" thus differed between the different steps in the process. Given these circumstances, in the From table to soil project, we identified several relationships of accountability.

Moving from the bottom and working our way up, we note that, at the project level, representatives from the three sectors were involved in the triple helix. All the interests that were represented in the triple helix thus met and intersected with each other at the project level. Again, at the project level, these actors were responsible for the outcome of the project, but they were also responsible for ensuring that the project delivered the outcomes that the stakeholders expected. It is, however, difficult to discern the extent to which any one actor involved in the triple helix represented his or her individual interests and the extent to which he or her represented the interests of their home organisation or that of the triple helix. This issue was mentioned in the evaluation report conducted by Vinnova when the decision was made that the RIS should not receive financing. Vinnova wrote:

It seems obvious that the commitment of most of the stakeholders is on an individual basis rather than at an institutional level and this inevitably becomes a constraint.

That it is difficult to know who certain participants represent in a triple helix constellation is something that has also been recognized in the literature on collaboration (Huxham, 2003) and is thus a problem that occurs in crosssectorial collaborations. According to Huxham (2003), this circumstance creates ambiguity and makes the collaboration vulnerable, since it is dependent on individual relationships and not institutional relationships.

We can thus, already see in the set-up of the triple helix (i.e. very early in the process) how problems related to accountability are likely to surface in terms of the relationships between actors who are involved in the triple helix. This includes internal and external stakeholders, too. Consequently, with regards to answering the question "Who is accountable to whom and for what?" the lines were blurred and it was not certain that the individuals who participated in the project recognized that they were accountable for the outcomes of the 
project they were a part of. The person who was to be held accountable needed to respond to the request by taking account, and the person who was to be held accountable needed to recognizes the authority or the right of the other person to hold him or her accountable (Greiling and Spraul, 2010; Gray and Jenkins, 1993; Sinclar, 1995; Broadbent et al., 1996). It is especially important that we address this issue here, since vertically, the individuals who constituted the From table to soil project group are to be held accountable to stakeholders in the organisation or sector where they are located. In turn, these organisations are responsible to the stakeholders of the RIs project. A summary of the findings from the empirical material building on the framework from Table 1, are presented in Table 3 .

As presented in Table 3, in the case of the representatives from the three municipalities that were involved in the project, we argue that they are accountable to the municipality where they are employed. The municipalities are, in turn, responsible to the governing politicians who are responsible towards the residents in the municipality regarding how they authorize the spending of public money. This chain of hierarchical accountability thus began at the individual level in the From table to soil project and ended at the governance level of the municipality. In this chain, accountability is thus claimed hierarchical in different steps, with the overall focus on public value. In this case, the intended public value was to reduce waste and to find more environmentally friendly solutions to waste disposal. Involved in achieving this were changes in the public's behaviour and the creation of knowledge about these processes. Since the public sector is the system owner, they have an interest in all of the four tasks that together comprised the From table to soil project.

Similarly, the representatives from the private sector who participated in the From table to soil project either represented their own organisation or a company by which they were employed. In either case, they represented the private sector, and their focus was on creating economic value by stimulating growth in the green sector of the economy (se summary Table 3). A main challenge for the private companies that participated in the RIS project was that the innovation process was an ongoing process, in the sense that there were no final products developed that could be sold on a market. Regarding the organic plastic bags, a local company with an innovative product was engaged to produce them. This company was part of the local industry park focusing on recycling waste. Regarding the second task, several companies pitched their ideas on how to improve the biofertilizer, and one of those developed a product.

Finally, academia (see Table 3) was represented by several researchers. Their focus was on documenting the results of the RIS project and on increasing 
TABLE 3 A summary of the analysis of the actors involved in the project Table to Soil and their influence on the content of the four steps in the process. The summary and the analysis are based on the framework presented in Table 1

Sector and actor
involved
Public sector
represented by three
municipalities
Private sector
represented by the
clean tech industry
in the region and
the innovator of the
plastic bag

$\begin{array}{ll}\text { Academia } & \text { Horizontal: } \\ \text { represented by } & \text { Academic values. } \\ \text { researchers from } & \text { Hierarchical: } \\ \text { the University in the } & \text { Performance. } \\ \text { region } & \end{array}$

Triple Helix - The Horizontal and RIS and its members hierarchical.
Type of accountability

Hierarchical:

Democratic system and the public organization.

Horizontal: The RIS project, From table to soil.

Hierarchical: Focus on performance. Horizontal: Rules of market and competition.

\section{Expected contribution and Involvement and influence on delivery outcome}

Hierarchical -public

organization with focus

on reduce waste and to

find more environmentally

friendly solutions to waste

disposal.

Horizontal: The RIS project with different stakeholders. Hierarchical: Performance with focus on creating economic value by stimulating growth in the green sector of the economy.

Horizontal: The RIS

project and the different stakeholders of the project.

\section{Research output focus}

on wicked problems and sustainable innovation.

Documentation of knowledge. Demand driven.

Combination of content from each step in the process- risk for multiple accountability disorder.
Involved in all four work-tasks. Influence extensive.

Predominantly involved in the second task, in the prior development of the plastic bag. The plastic bag was part of all four tasks. Also involved in task three. Influence low.

Involved in all four tasks, but not active participation and not influencing the outcome.

From table to soil project level. All four tasks intersected at the project level and thus also the expectations on outcome. The public side of the Triple Helix dominated the RIs.

SOURCE: THE TABLE IS CONSTRUCTED BY THE AUTHORS AND IS A SUMMARY OF THE RESULT FROM THE STUDY THAT USES TABLE 1 IN THIS ARTICLE AS A BACK-DROP. 
and disseminating knowledge about triple helix projects and how one might approach challenges related to wicked problems from a research perspective. From this perspective, the chain of accountability is less clear. Whilst the researcher protects the values of academia, they are also expected to present the results of their research in different forums. With respect to some industries, research can be demand-driven, that is to say, industry works in collaboration with academia to solve specific problems and challenges. With respect to urban supply systems, however, the first step is that the public sees a need for innovation, and demand innovation. One way to work under such circumstances is to invite interested parties to enter dialogue with each other. Another approach is to have academic researchers take active part in the development of new projects and/or solutions and document the knowledge created. For the project here studied, academia had a more passive role focusing on gathering and disseminating knowledge.

Each of the three different types of hierarchical accountability relations described here represents one third of the triple helix collaboration. Thus, the triple helix project described here was accountable to academia, the three municipalities, as well as the clean tech industry (see Tale 3). Consequently, with regards to the question "For what was the triple helix project accountable for?", the answer is all the above-mentioned expected outcomes. The relationship between the triple helix project and the three stakeholders (academia, the municipalities, and the clean tech industry) is, however, not hierarchical, but horizontal. It is horizontal, because none of the stakeholders owned or controlled the triple helix project. Instead, they were partners in the project.

In one sense, however, the one entity that did own the project was the RIS, having received funding from Vinnova. The triple helix project was thus accountable to the RIs, and here the relationship is once again hierarchical. The RIS, in turn, was accountable to Vinnova, but note that Vinnova expected economic growth. Vinnova could not exert control over the RIS, however, so the relationship was not vertical. Notwithstanding this, but the RIS depended on the funding it received from Vinnova. The requirements for this to continue, as stated in the application to Vinnova, was that the RIS stimulate growth and jobs in industries related to the green economy. To some extent, the expectations from academia overlapped with the expectations from the public sector, whilst the expectations from Vinnova overlapped with the expectations of the industry in the region. 
What we are thus confronted with in this case are a number of different accountability relationships, ranging from the individual level to the meso level (individual organisations in the public domain and the clean tech industry), to a more aggregated macro level, which was represented by the regional and national levels. In addition, the outcome of the RIS and the outcomes of the different projects that were organised by the RIS were expected to deliver differed from one relationship to the other. Thus, the mere construction of the triple helix created a complex web of relations between the entities that were to be held accountable and the entities that held them accountable. This complex web of accountability relationships created ambiguities and set the stage for conflict between the actors within the triple helix and their stakeholders. We thus conclude that a multiple accountability disorder (Koppell, 2005; Spicer, 2017) is inherent to the triple helix constellation and the question of "Who is accountable to whom and for what?" is particularly difficult to answer without thoroughly analysing the different relationships that exist in the constellation. To claim that the individuals who were part of the From table to soil project fully grasped all of these relationships is probably quite farfetched, especially since no one in the project, except the project leader, was responsible for securing the overall outcome of the project. On the contrary, each of the individuals who participated in the project protected the interests of the organisation and the sector he or she represented.

However, due to the fact that they were the owners of the proposed systems, and since the public sector assumed a more dominant role in the From table to soil project", the outcome of the project was more in line with the expectations of the public sector than those of the private sector, and thus also less in line with Vinnova's expectations. An important question that we should ask when we analyse accountability is, therefore, "Who owns the problem/challenge?" Since the public sector in the From table to soil project was not only the system owner, but also the key actor in the project, the municipalities dominate the process. Thus, we conclude that their interests prevailed, whilst the interest of the other stakeholders were forced into the background.

This dilemma could have been solved if the overall performance of the RIS fulfilled the expectations of Vinnova. However, this did not happen and was also something that was recognized in the evaluation of the RIS that Vinnova arranged. In the evaluation, the project-based arrangement of the RIS was mentioned as problematic, since there was no overall strategic purpose that brough the projects together. This state of affairs was described in the evaluation report in the following way: 
However, we are concerned that in some key areas the initiative falls short of having achieved what might be considered as key Vinnväxt milestones: 1. Clear, well understood and shared strategic plan with vision and operations; 2. A balanced triple helix; 3. Tangible outputs that can be traced back to the initiative and 4. Pathways to international excellence.

Each project at the RIS, on its own, could have been successful, but when they were combined with each other, they did not contribute to the overall expectations of Vinnova, as mentioned in the above extract from the evaluation report. Given this, it is not surprising that Vinnova decided to withdraw their funding for the project. This decision was based on the fact that the RIs, at least on a short-term basis, had failed to fulfil their overall expectations. The outcome of the RIS and the Vinnova funded project studied here is thus problematic since what Vinnova expect and what the RIS promised to deliver to Vinnova was not in line with the interests of the stakeholders from the public sector; neither on the individual level nor on the meso level. What we thus see here is that the expectations differed between local government and national government represented by Vinnova. This is in line with findings in previous research on triple helix stressing the importance of recognizing the different levels of public sector (Cai and Etzkowitz, 2020). The overall initiative was thus deemed a failure, by its not receiving further governmental funding. However, when we consider the activities that were organised and implemented by the RIS, it is problematic to define it as a failure. This leads us to the conclusion that we must evaluate RIs from different perspectives and on different levels, and we need to consider the dimension of time in our evaluation.

What we observed with respect to the RIS is how, when the public sector is the driving force in the innovation process in a triple helix collaboration, for-granted expectations regarding what the triple helix is to deliver are challenged. Instances of public sector organisations being involved in triple helix collaborations are scarce (Larsen et al., 2018). A more recent study by Larsen et al., (2018) has explored the role of the public sector in triple helix collaborations in Norway. However, in none of the five cases that were studied by the authors did the public sector assume an active role in the innovation process. Instead, what they observed was how the public sector assumed the role of regulator, facilitator, or funder (Larsen et al., 2018). Those roles are less problematic with regards to issues concerning accountability, since, when the government assumes one of these roles, it does so to support regional economic growth. Thus, in more traditional forms of triple helix collaboration, the expectations of the government are aligned with the general expectations of what the triple 
helix is supposed to deliver. In such cases, the issue of accountability becomes less of a challenge (Huse, 2005).

In the case studied for this article, all of these three roles were assumed by Vinnova, who also expected economic growth to be the outcome of the triple helix. In addition to the involvement from Vinnova, we observed a strong degree of involvement from the three municipalities in the region. These municipalities did not assume one of the three roles mentioned by Larsen et al., (2018), however. In their role as system owners, they took on a more active role in the innovation process, instead. This move resulted in a shift in output focus; a shift from economic growth to sustainable urban development. When such a shift in focus occurs, then the centre of gravity of the triple helix also shifts and, with that, the assumed alignment between the actors involved with regards to the expected outcomes no longer exists (Huse, 2005), thereby complicating the issue of what the triple helix is accountable for.

\section{New Perspectives on Triple Helix}

Based on the results from this study, we thus claim that there is a need to bring in new perspectives when working with triple helix, in both academia and in practice. In today's society there is an increasing need to engage in cross-sector collaborations to address wicked problems involving urban supply systems where the public sector is the system owner, then we need to re-evaluate the idea of a triple helix. For one, we need to recognize (i) the importance of the triple helix in the context of addressing wicked issues and recognize (ii) that the public sector can take a leading role in innovation processes.

Secondly, and following on from the first observation, public sector is not one single sector (Cai and Etzkowitz, 2020). Consequently, different layers of the public sector can assume different roles in the triple helix collaboration and thus also have different expectations. Therefore, we need to recognize that a triple helix collaboration should not only focus on economic growth, but also take into consideration social value and the creation of knowledge regarding how to approach wicked issues, like sustainable urban development. This leads us to the third point: we need to also reconsider the "For what?" question with regards to holding triple helix collaborations accountable. Economic growth should not be the default option or default goal. Instead, the purpose of a triple helix should determine what the triple helix is accountable for. A triple helix is not a failure just because it does not deliver economic growth. On the contrary, a triple helix can be successful if it contributes to our knowledge 
of how to address wicked issues and thereby create social value. Finally, the fourth point we would like to make is that one should consider the time frame. Wicked questions like the question that the RIS was assigned to address cannot be readily solved over just a three- or five-year period. The results of such work take more time than that to be realised. Unfortunately, Vinnova expect short-term results from this project, which turned out to be problematic for the From table to soil project. Thus, when one re-evaluates what a triple helix collaboration is to be held accountable for, then a different time frame and different measures need to be considered. This is especially the case for those triple helix collaborations where the public sector assumes a prominent role.

\section{Conclusion}

The purpose of this study was to apply the concept of "accountability" in our description and analysis of "Who is accountable to whom and for what?" in a triple helix collaboration in which the public sector played an important role. By studying a specific project within the triple helix constellation, we were able to discern different lines of accountability. We also note that the context of a triple helix collaboration creates a complex web of different relationships in which accountability can be, and is, claimed. These relationships run vertically as well as horizontally in the triple helix framework, and they span over several levels of the organisation: from the individual level, to the meso level, and all the way up to the system level. A "multiple accountability disorder" (Koppell, 2005) is thus inherent to the triple helix constellation, thereby making it difficult for the researcher to discern who is accountable to whom. This is further accentuated by the fact that public sector consists of different layers and that each layer can have different expectations on the triple helix. This study thus confirms findings in more recent research on triple helix collaboration stating that in order to fully understand the dilemmas of triple helix collaborations, we cannot treat public sector as one sector (Cai and Etzkowitz, 2020; Liu and Cai, 2018). However, despite this complex web of accountability relationships, it has been the case that, traditionally, triple helix collaborations have been able to fulfil stakeholders' expectations, as long as the outcomes of the collaboration generate economic growth. This situation will be realised, as long as the "For what?" question remains somewhat simple to answer and an alignment of interests can be achieved (Huse, 2005). When the triple helix model was first developed by Etzkowitz and Leydesdorff (2000), they stated that academia, government, and industry together would create a knowledge infrastructure with overlapping institutional spheres, with the resulting emergence of hybrid 
organisations. The role of the government was initially envisaged to, primarily, support and encourage, not to control, or, as described by Larsen et al. (2018), to facilitate, regulate and/or finance the triple helix collaboration. However, with the case we have described in this study, the role of the government (i.e., the public sector) is different to what was first envisaged by Etzkowitz and Leydesdorff (2000), because urban supply systems are the responsibility of a local government, i.e., a municipality. In the present case, the public sector organisations involved thus broke away from their traditional roles and, consequently, the question of "For what?" the triple helix was accountable for became less clear. From this case study, we observe how the power relationships between organisations that participate in a triple helix shift from (a) the traditional focus on private sector companies to (b) the government, or in this case, a conglomeration of municipalities. When it was decided that the RIS was not to receive further financial support from Vinnova, one point of criticism that was raised by the evaluators was based on a perceived imbalance in the triple helix constellation. The evaluators thought that the role of the private businesses and academia had been pushed to the background, whilst they thought that the helix that represented the government was far too dominant. This observation is accurate, since we also observed that the municipalities were dominant in the context of the triple helix because this was the arena for urban development projects. This study thus challenges existing beliefs in the triple helix model and the notion that innovation can be driven merely by the private sector with support from government funding and an entrepreneurial university. This prompts us to ask whether we need to re-evaluate the role of the government in a triple helix constellation. In this context, we propose that the purpose of the triple helix should define where the centre of gravity of the triple helix should be and thus what the triple helix should be held accountable for. We need to redefine the idea of the triple helix as a vehicle for economic growth and recognize the potential that cross-sector collaboration has for addressing wicked issues. Doing so will thus generate not only economic value, but also social value. To accomplish this, we need to redefine the role of the public sector in triple helix collaborations. It is of importance to notice that different public actors have different roles to shoulder. First, there are different levels of the public spanning from the global level to the local; second public actors take different forms from public companies to public organizations. We argue for more research on what roles and responsibilities public actors, like, for example, local government has when it comes to issues related to sustainability as well as innovation in urban settings. The question of the responsibility of municipalities is in turn closely related to the question of accountability (Koppell, 2005). If municipalities are held accountable for how 
they work with sustainability issues and recognize that they are accountable for those issues they will be able to take a leading role. More research is thus needed in relation to sustainability and accountability in a municipal setting and how municipalities can take a leading role in innovation processes aiming to increase sustainability in urban settings.

That issues of accountability emerge in cross-sector collaborations is not a new phenomenon or unique to this case. The complexity generated by multiple relationships of accountability is present in all types of cross-sector collaborations. It is therefore no surprise that the main issues that are raised in the context of cross-sector collaboration and governance networks are related to governance and, more precisely, how one is to establish trust and ensure accountability (Huxham, 2003; Klijn, 2008; Klijn et al., 2010). This case is just yet another example of this. However, the problems still remain, and perhaps even more so when one of the actors breaks away from traditional roles and expectations and assumes a new position within the collaboration.

Like all studies, this study has limitations. This study is based on one single case study. More research on the issue of accountability in relation to the triple helix model is therefore needed. For similar reasons more studies investigating the role of public sector in triple helix collaborations are needed. With this in mind, we thus call for more studies on the issue of accountability in crosssector collaborations, and how the governance of these collaborations can align the various parties' interests and properly address the issue of accountability. In addition, more research on power-(im)balances and asymmetries and how they can be addressed in cross sector collaborations at the governance level, as well as within organisations or in specific triple helix projects is needed. We also call for more studies on the role of the public sector in triple helix collaborations and how the role of public sector influences the goals of triple helix collaborations.

\section{Note}

1. It could be argued that this case is a cluster and not a RIS. However, as the initiative received funding from Vinnova in a program supporting RIS we have decided to discuss it in terms of a RIs. As the story tells, Vinnova decided to withdraw the funding which implies that it did never develop to a flourishing RIS. 


\section{Acknowledgement}

This study is partly funded by Vinnova, partly by the Flexit Project of the Swedish Riksbankens Jubileumsfond: RMP18-o988:1, and partly by The Crafoord Foundation.

\section{References}

Asheim B and Isaksen A (2002) Regional innovation systems: the integration of local "sticky" and global "ubiquitous" knowledge. Journal of Technology Transfer 27: 77-86.

Attonen M, Lammi M, Mykkänen J and Repo P (2018) Circular economy in the triple helix of innovation systems. Sustainability 10(2646);1-14. DoI: 10.339o/su1oo82646. Bovens M (2007) Analysing and assessing accountability: a conceptual framework. European Law Journal 13(4): 447-468.

Bovens M (2009) Public accountability. In: Ewan F, Laurence EL and Pollitt C (eds) The Oxford Handbook of Public Management. Oxford: Oxford Handbooks Online, $182-208$.

Bracci E, Humphrey C, Moll J and Steccolini I (2015) Public sector accounting, accountability and austerity: more than balancing the books? Accounting, Auditing and Accountability Journal 28(6): 878-908.

Brown JT (2017) The seven silos of accountability in higher education: systematizing multiple logics and fields. Research and Practice in Assessment 11: 41-58.

Cai Y and Etzkowitz H (2020) Theorizing the triple helix model: past, present and future. Triple Helix 7: 189-226.

Cooke P (2005) Regionally asymmetric knowledge capabilities and open innovation exploring "globalisation 2 " - a new model of industry organization. Research Policy 34(8): 1128-1149.

Cooley A (2020) Comparative analysis of online accountability practices in three sectors: private, public and nonprofit. Accounting, Auditing and Accountability Journal 33(6): 1423-1445.

Cooper SM and Owen DL (2007) Corporate social reporting and stakeholder accountability: the missing link. Accounting, Organizations and Society 32(7/8): 649-667.

Cordery C, Baskerville R and Porter B (2010) Control or collaboration? Contrasting accountability relationships in the primary health sector. Accounting, Auditing and Accountability Journal 23(6): 793-813.

Etzkowitz H and Leydersdorff L (2000) The dynamics of innovation: from National Systems and "Mode 2" to a triple helix of university-industry-government relations. Research Policy 29(2): 109-123. 
Etzkowitz $\mathrm{H}$ and Klofsten M (2005) The innovating region: toward a theory of knowledge-based regional development. R\&D Management 35(39): 243-255.

Foss Hansen H, Geschwind L, Kivistö J, Pekkola E, Pinheiro R and Pulkkinen K (2019) Balancing accountability and trust: university reforms in the Nordic countries. Higher Education 78: 557-573.

Freeman C (1987) Technology Policy and Economic Performance: Lessons from Japan. London: Frances Printer.

Godin, B., 2006. The linear model of innovation: the historical construction of an analytic framework. Science, Technology \& Human Values 31 (6), 631-667.

Gray A and Jenkins B (1993) Codes of accountability in the new public sector. Accounting, Auditing \& Accountability Journal 6(3): 52-67.

Greiling D and Spraul K (2010) Accountability and the challenges of information disclosure. Public Administration Quarterly Fall: 338-375.

Head B and Alford J (2015) Wicked problems: implications for public policy and management. Administration \& Society 47(6): 711-739.

Hodges R (2012) Joined-up government and the challenges to accounting and accountability researchers. Financial Accountability and Management 28(1):26-51.

Huisman J and Currie J (2004) Accountability in higher education: bridge over troubled water? Higher Education 48: 529-551.

Huse M (2005) Accountability and creating accountability: a framework for exploring behavioural perspectives of corporate governance. British Journal of Management 16: 65-79.

Huxham C (2003) Theorizing collaborative practice. Public Management Review 5(3): 401-423.

Jacob M (2006) Utilization of social science knowledge in science policy: systems of innovation, triple helix and VINNOVA. Social Science Information 45(3): 431-462.

Kearns KP (1998) Institutional accountability in higher education: a strategic approach. Public Productivity and Management Review 22(2): 140-156.

Isaksen, A. and Nilsson, M. (2013) Combined innovation policy: linking scientific and practical knowledge in innovation systems. European Planning Studies 21(12): $1919-1936$.

Klijn E-H (2008) Governance and governance networks in Europe. Public Management Review $10(4): 506-525$.

Klijn E-H, Steijn B and Edelenbos J (2010) The impact of network management on outcomes in governance networks. Public Administration 88(4): 1063-1082.

Koppell JGS (2005) Pathologies of accountability: ICANN and the challenge of "multiple accountability disorder". Public Administration Review 65(1): 94-108.

Larsen Ö, Nesse JG and Rubach S (2018) The public sector's role in Norwegian network cooperation: triple helix or laissez-faire. Triple Helix 5(4): 1-25. 
Liu C and Cai Y (2018) Triple helix model and institutional logics in Shenzhen Special Economic Zone. Science and Public Policy 45(2): 221-231.

Lundvall BÅ (1988) Innovation as an interactive process: from user-producer interaction to the national system of innovation. In: Dois G (ed.) Technical Change and Economic Theory. London: Printer.

Lundvall BÅ (1992) National Systems of Innovation: Towards a Theory of Innovation and Interactive Learning. London: Printer.

Macfarlane B and Burg D (2019) Legitimation, professionalisation and accountability in higher education studies: an intergenerational story. Studies in Higher Education 44(3): 459-469.

McIntyre A (2008) Participatory Action Research. Thousand Oaks, CA: Sage.

Morgera E (2020) Corporate Environmental Accountability in International Law. Oxford: Oxford University Press.

Mulgan R (2000) "Accountability": an ever-expanding concept? Public Administration $78(3): 555^{-573}$.

Munro R and Mouritsen J (eds) (1996) Accountability: Power, Ethos and the Technologies of Managing. London: International Thompson Publishing.

O'Dwyer B and Unerman J (2007) From functional to social accountability: transforming the accountability relationship between funders and non-governmental development organisations. Accounting, Auditing and Accountability Journal 20(3): 446-471.

Prasad P (2005) Crafting Qualitative Research - Working in the Post-positivist Traditions. New York: M. E. Sharpe.

Rittel HWJ and Webber MM (1973) Dilemmas in a general theory of planning. Policy Sciences 4(2): 155-169.

Roberts J and Scapens R (1985) Accounting systems and systems of accountability understanding accounting practices in their organisational contexts. Accounting, Organization and Society 10(4): 443-456.

Romzek BS and Dubnick MJ (1987) Accountability in the public sector: lessons from the Challenger tragedy. Public Administration Review 47(3): 227-238.

Shaoul J, Stafford A and Stapelton P (2012) Accountability and corporate governance of public private partnerships. Critical Perspectives on Accounting 23: 213-229.

Sharif N (2006) Emergence and development of the National Innovation System concept. Research Policy 35(5): 745-766.

Sinclair A (1995) The chameleon of accountability: forms and discourses, Accounting Organizations and Society 2O(2/3): 219-237.

Solli R and Jönsson S (1997) Housekeeping? Yes, but which house? Meaning and accounting context - A case study. Scandinavian Journal of Management 13(1): $19-38$. 
Spicer Z (2017) Bridging the accountability and transparency gap in inter-municipal collaboration. Local Government Studies 43(3):388-407.

Thomasson A and Wigren Kristoferson C (2020) Hybridizing the triple helix: a prerequisite for managing wicked issues. Financial Accountability and Management 36 : 207-222.

Watson D (2003) The rise and rise of public private partnerships: challenges for public accountability. Australian Accounting Review 13(3): 2-14.

Willems T and Van Dooren W (2012) Coming to terms with accountability: combining multiple forums and functions. Public Management Review 14(7):1011-1036.

Zambon S and Del Bello A (2005) Towards a stakeholder responsible approach: the constructive role of reporting. Corporate Governance. The International Journal of Business in Society 5(2): 130-141. 